Article

\title{
The Influence of Teacher Expectancy Improvement Strategies on Student Attitude and Achievement in English Courses (An Action Research Sample) ${ }^{\dagger}$
}

\author{
Selnur Toksoy ${ }^{1, *}$ and Filiz Evran Acar ${ }^{2}$ (D) \\ 1 Independent Researcher, Sakarya 54050, Turkey \\ 2 Faculty of Education, Department of Education Sciences, Düzce University, Düzce 81620, Turkey; \\ filizacar@duzce.edu.tr \\ * Correspondence: selnuryuksel89@gmail.com \\ $\dagger$ This study was produced as Selnur Toksoy's Master's thesis which was carried out under the consultancy of \\ Filiz Evran Acar.
}

Received: 16 November 2018; Accepted: 13 January 2019; Published: 22 January 2019

check for updates

\begin{abstract}
The aim of this study is to investigate the influence of teacher expectancy improvement strategies on student achievements and attitudes in English courses. We investigated the existing situation, and have presented a method that can provide the educational processes necessary to bring about the required changes. For this reason, the emancipatory/improving/critical action research model was used. The study was carried out on a sample group consisting of 87 students, 43 sixth graders, and 44 eighth graders, attending a school located in Düzce's city center during the 2015-2016 academic year. In order to collect the data, the "Teacher Expectancy Scale" that was developed by the researchers, as well as the "Attitude Scale towards English Course", and a further seven tests, which were prepared by the Turkish Ministry of National Education (MoNE), were used. The study was conducted for a total of 48 hours over 12 weeks, for four hours per week. As a result of the study, it was revealed that teacher expectations influenced the attitudes of the students towards the English lesson in a positive way, and increased their academic achievements.
\end{abstract}

Keywords: foreign language teaching; teacher expectation; expectancy strategies; attitude; academic achievement

\section{Introduction}

Throughout history, people have felt the need for communication with one another. Language is the most important element of communication, and this separates humans from other organisms. It also allows people who use the same language to understand each other. Due to our ability to learn, people from different countries are also provided with opportunities to communicate with each other [1].

All languages, except the mother tongue that a nation speaks in its own constitution, and that which is shared by members of the nation, are constituted as foreign languages [2]. Foreign language teaching is the process of teaching another language that has different structure, concepts, and grammatical rules from the native language [3].

The importance that is given to foreign language learning has gained momentum in Turkey, with developing technology, and with the need for accommodation to the world. One milestone for foreign language teaching in Turkey was the declaration of the republic; it emphasizes movement towards western states, to establish closer relationships. In 1928, the Turkish Education Association (TED) was founded, in order to terminate the dependency on foreign colleges in order to learn foreign languages; foreign language teaching was mentioned in the formal reports prepared by the Ministry of Education 
and the foundations of foreign language teaching were laid with the enactment of the Law on Foreign Language Education and Teaching in Turkey [2].

However, improvements in the education system did not lead to improved foreign language teaching. When the reasons for the failure were analyzed, it was concluded that the physical condition of the classrooms, crowded classrooms, the ineffectiveness of the foreign language policies, traditional ways of learning foreign languages, a lack of motivation for students to achieve satisfactory grades and pass the class, not enough use of creative methods for language teaching, deficiencies related to the methods or techniques, materials, and assessments might be counted as the possible causes [4-6].

What is more, negative views, attitudes towards foreign language learning, anxiety, and a lack of motivation are major barriers preventing success $[7,8]$. Unless negative attitudes are precisely specified and modified, students will not make the effort to learn a foreign language [9]. In order to increase success, it is vital to motivate students, and to have them develop positive attitudes $[10,11]$.

The fact is that there is a relationship between teacher expectancy and academic success, and the influence of this relationship is maintained throughout a student's life [12]. The foundations of teacher expectancy date back to the study carried out by Rosenthal and Jacobson in 1968, in California. Rosenthal and Jacobson told teachers in their study that a number of randomly selected students achieved higher scores from the test, and their progress was supposed to be notable. As a result, those students made the expected progress, and the scores that they achieved were high. Teachers' behaviors, attitudes, and beliefs produce changes in the students' behaviors as well. When teachers manage to make an impression on their students, students' behaviors-which are shaped through the teachers' expectations-also motivate them. If a student's behavior is shaped in accordance with the teacher's expectations and it is maintained, and the student does not resist expectations, an expected behavior is created. If the expectations are positive and the classroom atmosphere is designed accordingly, these expectations direct the student towards achievement. On the other hand, if the expectations are negative and the students are given negative messages, the atmosphere is unfavorable, and the expectations misdirect the students towards failure [13-15]. Teacher expectations have significant effects on estimating student outcomes, but more importantly, they also influence outcomes by becoming self-fulfilling prophecies [16]. A teacher's expectations might cause learned helplessness for the student. In this case, the student does not strive to do better, since he/she presumes that the teacher would not notice his/her efforts, contradictory to the expectations. The possibility of a teacher realizing and relieving the student from learned helplessness depends on the flexibility of his/her expectations [12].

Teachers might be inclined to classify their students with regard to their perceptions, attitudes, and their students' qualifications. Such classifications might shape their behavior. The behaviors that shape their expectations are usual to some extent—but it is improper if the teachers behave under the influence of their expectations [12]. Teachers shape their behavior depending on the students' manners, which are generally influenced by the following [17]:

- The quality of the questions and answers,

- The time allocated for answers,

- The need to give clues,

- The quality and quantity of the feedback and rewards,

- Giving opportunities for speaking and participating in activities,

- Interrupting, reprimanding,

- Trusting students,

- Physical-emotional affection.

Brophy and Good [18] studied the interaction between teachers and students with a high/low level of teacher expectancy. The basic difference in the teacher's behavior was found to be between the levels of criticism and praise. It was seen that the teacher praised less when the student for whom he/she had a low level of expectancy performed a positive behavior, and criticized more when the 
students did something negative. Secondly, there was also another difference in giving feedback. While the percentage of teachers misjudging feedback times for students that had a higher level of expectancy for was 3\%, the incorrect timing percentage increased to $15 \%$ for students for whom they had lower expectancy levels. Another difference was seen in encouraging the students to find accurate answers, giving them clues, and helping. The teachers performed activities such as question repetition, giving clues, and asking the question in different ways, more often for students for whom they had higher expectations.

Allington [19] stated in the study that teachers focused highly on the phonetic skills of their students, and provided immediate correction for them, instead of focusing on comprehension skills during reading tasks for the students that had lower expectancy levels. According to the study carried out by Cooper and Tom [20], teachers replied less often to questions, made eye contact, and smiled less frequently to the students that had lower expectancies.

Similarly, Öztürk, Koç, and Şahin [21] found out that $92.8 \%$ of the teachers behaved differently to students, depending on their expectancy levels. A total of $69.1 \%$ of the students sat at the front desks. Öztürk et al. [17] stated that in another study involving 81 teachers the teachers asked questions that needed students' interpretation, and they trusted the students that had higher expectations; while students with lower expectations had their mistakes corrected, and were reminded how they had to work more.

Previous studies also showed that teachers asked harder questions, allocated more time, gave hints for answers, behaved more moderately, and gave the right to speak more frequently when asked questions, gave more positive feedback, ignored misbehavior, warned less commonly, and paid more attention to the students that had higher expectations and who were perceived as being more successful. On the other hand, the teachers seldom gave students with lower expectations the right to speak, and perceived them as being unsuccessful, would distance themselves from these students, paid them less attention, allocated less time for questions, rarely gave clues, asked simpler questions, interrupted them more often, and criticized those students more.

Teachers' higher expectations and influence on students' academic success in positive ways gives positive results for self-actualization [22]. A teacher needs to manage his/her expectations, both to realize self-actualization, and to educate the students better. By managing his/her own expectations, a teacher might put an end to behavioral diversities, form higher expectations for each student, and conduct his/her behavior accordingly. An effective teacher should always have higher expectations for his/her students, and reveal these expectations orally and physically [23]. Aside from these, if teachers would like to enhance their classroom climate and support students' self-regulation through goal-setting and feedback, they should use flexible grouping with greater activity choices [24].

The first step to creating higher expectation is to design a positive classroom atmosphere. A teacher should be positive, clear, and consistent in their communication with the students. Opportunities to praise students should be created, criticisms need to be respectful, and they should draw attention to efforts without disregarding mistakes. In order to increase the quality in the students' answers, the time allocated to the students to respond to the questions should be prolonged and the duration should be well-planned. The questions should be designed beyond just knowledge, which is the first phase of the cognitive domain. Instead, the questions should direct the students to think, and they should be designed in the analysis, synthesis, and evaluation phases in the hierarchy [25]. The teacher should perform the following tasks to diminish the influence of negative expectations, and should move the influence of positive expectations to the highest level [13]:

1. A teacher should focus on how to teach,

2. The existing performance, rather than former performance, should be emphasized,

3. Goals should be set in accordance with standards,

4. Plans suitable to the existing performance levels of the students should be prepared, and students should be provided with feedback concerning their performance, 
5. Feedback should stress reaching an accurate piece of knowledge, instead of focusing on success/failure,

6. Modifications should be made when the students have problems with understanding, an explanation/activity should be used instead of repeating the same explanation.

7. Students should be encouraged, rather than trying to prevent them from making mistakes.

A society named Teach for America (TFA) was founded in 2009 to provide equal opportunity in education for schools located in rural areas. TFA aspires to have higher expectations for students to meet the deficits, due to the inequalities between students. As the result of the studies, TFA specified four characteristics of teachers who managed to be successful with students living in rural areas, and whose families had lower income levels, in the book "Teaching as Leadership" [26]:

- The teacher sets goals which are attainable by the students with their own efforts,

- The teacher obtains information about the students,

- The teacher struggles in determination and gets over the handicaps,

- The teacher makes self-assessments, and continuously improves his/her performance with care.

Another initiative on the issue is the Southern Regional Education Board (SREB), an association that was established in 1948, which considers the relationship between education and economic recovery. The board forms regulations that are related to education in Southern American states, together with providing accurate and independent information. As a result of the studies carried out by SREB, Reynold [27] defined 10 strategic points to create higher-expectation atmospheres in the classrooms. These points are:

1. Preparing, improving, and implementing a classroom motivation and management plan (a classroom motivation and management plan includes teaching goals and outcomes, classroom rules, student behavior, expected performances and results, rewards, details related with extra help, opportunities, and communication plans),

2. Developing plans that enable the teacher to increase the allocated time for individual students to a maximum level,

3. Making classroom organizations stimulating, in order for students to produce new ideas,

4. Creating academic expectations,

5. Sharing these expectations with students and parents,

6. Implementing activities that are aimed at active student participation,

7. Entrusting students with some tasks, in accordance with the classroom objectives,

8. Motivating students by providing clear feedback related to the given tasks,

9. Avoiding disappointment by designing exercises that are appropriate for a diverse levels of students,

10. Coping with impolite behavior.

In addition to the studies mentioned, there are training activities that are designed for teachers. One of the remarkable examples of these training activities is the Teacher Expectation Student Achievement (TESA). TESA is an educational program which leads to behavioral changes based on expectancy theory; it is designed to reduce the negative influence of teacher expectations, and to improve a teacher's awareness [28,29]. The Los Angeles Country Office of Education (LACOE) developed TESA in 1971, specifically a team led by Dr. May Martin. In this program, teachers are encouraged regarding issues such as giving opportunities, providing feedback, praising, and establishing respectful relations with the students. TESA gives the chance to communicate effectively, and adequately with each student, regardless of personal differences [28]. TESA includes 15 interactive behaviors, which are placed under five units in three main sections. The main sections are based on academic success, positive feedback, and providing self-confidence. The 15 interactive behaviors are listed below [28]: 
- Equitable distribution

- Individual help

- Latency

- Delving

- Higher-level questioning

- Affirmation/correction

- Praise

- Reason for praise

- Listening

- Accepting feelings

- Proximity

- Courtesy

- Personal interests and compliments

- Touching

- Desisting

As the related literature is reviewed, it could be noticed that a teacher's expectation has a significant effect on improving the students' interests in courses, their views, and their academic success. Teachers might also make use of some strategies to make his/her expectations higher. Accordingly, in the existing study, the influence of teacher expectancy improvement strategies on the students' attitudes and success in an English course was examined. The aim was to increase their success rates with their positive attitudes towards the English course. The research problem was defined as "What was the influence of teacher expectancy improvement strategies on the students' attitudes and success in English courses?" I tried to answer the following questions in the study:

- Did teacher expectancy improvement strategies create any significant differences in students' expectations about the teacher, before and after the implementation?

- Did teacher expectancy improvement strategies create any significant differences in students' attitudes towards the English course, before and after the implementation?

- Did teacher expectancy improvement strategies create any significant differences in students' average scores from the English tests, before and after the implementation?

- What was the influence of teacher expectancy on the students' attitudes towards the English course?

- What was the influence of teacher expectancy on the students' success rates in the English course?

\section{Method}

\subsection{The Research Model}

In the study, an existing situation was defined, and a process that could change and improve educational procedures was discussed. For that reason, the emancipatory/improving/critical action research model was used. In this action research model, new information, abilities, or experiences are attempted to be gained by the implementer, or the implementer himself assesses his own implementations from a critical point of view [30].

Action research is a systematic scientific process based on people taking action to develop change by investigating their own professional development [31,32]. Action research provides an increase in the quality of education, and the enrichment of the professional experience for teachers [33]. It aims to realize educational development, and to directly change the research process [30].

According to Mills [34], action research is a dialectical cycle with four steps. In the first step, the focal point is identified. In the existing study, the teacher expectancy factor was addressed as the focal point, since it was considered to influence the students' attitudes and success rates. Data is 
collected in the second step. In the study, the related literature was reviewed, to examine the teacher expectancy factor comprehensively, and to gather information on the issue. With the information gathered through the review process, a scale was developed, in order to define teacher expectancy. The third step was data analysis and interpretation of the analysis. In the study, the major sources of the problem and other factors influencing teacher expectancy were defined using the teacher expectancy definition scale and an attitude scale. The last step was the preparation of the action plan. In the study, 12-week-action plans were prepared, based on the collected data, and necessary observations were made, taking essential notes.

\subsection{Study Group}

The study was carried out on a study group consisting of 87 students; 43 sixth graders and 44 eighth graders attending a school located in Düzce's city center during the 2015-2016 academic year. While determining the study group, the group was selected from students whom the researcher taught, and it was also important in the selection of the study group that the researcher had taught English to the selected group of students during the 2014-2015 academic year. Therefore, another teacher's negative influence on internal validity was to be kept under control, and to be prevented. As the students knew their teacher (researcher) before, it was presumed that, based on the observation, the students' responses to implemented scales would be more reliable, and the data would be more accurate.

\subsection{Instruments for Data Collection}

As one of the data collection instruments of the study, the "Teacher Expectancy Definition Scale" was developed by the researcher to determine the deficiencies in teachers' expectations regarding behavior and to measure their expectancy levels; the "Attitude Scale towards English Course" developed by Kirkız [35] was used to measure the students' attitudes; and the seven revision tests developed by MoNE were used to determine the students' English academic achievement scores.

Teacher Expectancy Definition Scale: During the preparation of the statements included in the scale to determine teacher expectancy, the TESA training program was implemented by teachers in the U.S, and teacher behaviors-which were specified in the previous studies-were taken into consideration. For the content validity of the Teacher Expectancy Definition Scale, 10 educational specialists were asked for their views. The assessment of their views was done with consideration of the Davis technique. As a result of the content validity analysis, the sixth, 15th, 25th, and 44th items were excluded from the scale. Necessary revisions were made for the eighth, ninth, 14th, and 41st items. The final version of the scale had 40 total items; 31 positive and nine negative. The scale was a 5-point-Likert scale, and the respondents were asked to choose the most appropriate response, for themselves, between always, usually, sometimes, rarely, and never. Students' choices were scored, with the numbers between 5 to 1 , starting from "always" for the positive responses, and the scoring for the negative items started from 1 to 5 .

The statements were gathered under four headings as: equal treatment, giving clues, intimacy, and motivation. They were grouped as the results of the defined factors that influenced teacher expectancy upon a review of the related literature, and the previous research and the factor structure were also analyzed with Confirmatory Factor Analysis (CFA). Accordingly, the factor loads (Lambda) of the items in the scale, the squared value of the multiple correlations (R2), which determines the strength of the relationship between each item, and the implicit variable and $t$-values, represent the significance of the calculated relationship. According to the results, except for the 32nd item placed under the equal treatment sub-dimension, the $t$-values of all of the items were seen to be significant. It was interpreted that the observed data with the fit indexes were adapted to the model. The fit indexes of the model with four sub-dimensions and 40 items are shown in Table 1. 
Table 1. Goodness Fit Index for the Factor Structure of Teacher Expectancy Determination Scale Items.

\begin{tabular}{ccc}
\hline Goodness Fit Index & Acceptable Limit & Value \\
\hline$X^{2} / \mathrm{df}$ & $<5$ Average; $<3$ Good & $1065.71 / 734=1.45$ \\
GFI & $>0.90$ & 0.71 \\
CFI & $>0.90$ & 0.94 \\
NFI & $>0.90$ & 0.88 \\
NNFI & $>0.90$ & 0.93 \\
RFI & $>0.85$ & 0.87 \\
S-RMR & $<0.08$ & 0.072 \\
RMSEA & $<0.08$ & 0.051 \\
\hline
\end{tabular}

Note: GFI: the goodness-fit index; CFI: the comparative fit index; NFI: the normed fit index; NNFI: Non-Normed Fit Index; RFI: the relative fit index; S-RMR: the standardized root mean residual; RMSEA: the root mean square error of approximation

As seen in Table 1, the chi square test benchmark rate was $X^{2}(734)=1065.71, p<0.01$, the root mean square error of approximation was $($ RMSEA $)=0.051$; the standardized root mean residual was $(\mathrm{S}-\mathrm{RMR})=0.072$; the comparative fit index was $(\mathrm{CFI})=0.94$; the goodness-fit index $(\mathrm{GFI})=0.71$; the normed fit index was (NFI) $=0.88$; the relative fit index was (RFI) $=0.87$. As the result of confirmatory factor analysis, a four-factored-structure of the scale was found to be between acceptable values.

The reliability of the scale was tested with the Cronbach Alpha coefficient. The reliability coefficient of the 40-item-Teacher Expectancy Definition Scale was found to be 0.983 .

A 12-week-course schedule was prepared based on the four major criterion, and courses were given accordingly; notes concerning implementations and observations were also taken.

Attitude Scale towards English Course: Necessary data related to the students' attitudes towards the English course was collected with the Attitude Scale towards English Course by Kırkız [35], which was an adapted version of the "Attitude Scale towards Geography Course" developed by Güven and Uzman. The scale had 10 positive and 10 negative statements related to the attitudes towards the course. This scale was also a 5-point-Likert scale, with responses like "Completely Agree, Agree, Neutral, Disagree, and Completely Disagree". The items of the scale were scored, considering the statements' being positive or negative; the positive ones were scored descending from $5-1$, and the negative ones were the other way round, ascending from 1 to 5 . The highest score available for the students' responses on the scale was 100, and the lowest score was 20. A score of 100 points showed the student's positive attitudes towards the English course, while 20 points showed negative attitudes.

Confirmatory factor analysis was used to analyze the data collected from the study group with the scale. According to the CFA result, the t-values of all of the items were seen to be significant $(p<0.05)$. The fit index of the 20-item-model used to measure the attitudes towards the English course is shown in Table 2.

Table 2. Goodness-Fit Index for the Factor Structure of Attitude Scale towards the English Course.

\begin{tabular}{ccc}
\hline Goodness Fit Index & Acceptable Limit & Value \\
\hline $\mathrm{X}^{2} / \mathrm{df}$ & $<5$ Average; $<3$ Good & $330.61 / 171=1.93$ \\
GFI & $>0.90$ & 0.82 \\
CFI & $>0.90$ & 0.94 \\
NFI & $>0.90$ & 0.90 \\
NNFI & $>0.90$ & 0.94 \\
RFI & $>0.85$ & 0.89 \\
S-RMR & $<0.08$ & 0.07 \\
RMSEA & $<0.08$ & 0.074 \\
\hline
\end{tabular}

As seen in the Table 2, the chi square test benchmark rate was $X^{2}(171)=330.61, p<0.01$, the root mean square error of approximation was $($ RMSEA) $=0.074$; the standardized root mean residual was $(\mathrm{S}-\mathrm{RMR})=0.07$; the comparative fit index was $(\mathrm{CFI})=0.94$; the goodness fit index $(\mathrm{GFI})=0.82$; the 
normed fit index was $(\mathrm{NFI})=0.90$; the relative fit index was $(\mathrm{RFI})=0.89$. As the result of confirmatory factor analysis, the uni-factored structure of the scale was found to be between acceptable values.

The reliability of the scale was tested with the Cronbach Alpha coefficient. The reliability coefficient of the 20-item-Attitude Scale towards the English Course was found to be 0.892 .

Student Success Tests: In order to decide the existing academic success rates of the students, six revision tests were implemented during the 12 weeks of training for the improvement of teacher expectancy between November and April in the 2015-2016 academic year, and one test was implemented at the end of the training. In total, seven revision tests were implemented. The revision tests had 20 multiple choice questions, and the correction formula for the scores were not used. The first test was implemented during the final week of November, the second test was implemented during the third week of December, and the third test was implemented during the first week of January. Tests were suspended due to the semester holiday until the third week of February. The fourth test was implemented during the third week of February, the fifth test was implemented during the second week of March, the sixth test was implemented during the first week of April, and the last test was implemented during the final week of April.

\subsection{Implementation Process}

Necessary data was collected from the sixth and eighth-grade students of a school located in Düzce's city center in the 2015-2016 academic year. The length of the study was 48 hours in total; four hours a week for 12 weeks. Pilot tests of the Attitude Scale for English Course and the Teachers Expectancy Definition Scale were carried out during the second week of November. After the pilot tests, the 12-week-implementation of the revision tests were maintained. The post-test implementation was done during the final week of April.

Upon the literature review, the activities realized between December-April were categorized under four subheadings, such as; equal treatment/behaving in a fair way, giving clues/supporting, intimacy/interest/valuing, and appreciating motivation.

\subsubsection{As a Part of Equal Treatment/Behavior as the Subheading}

Activities were realized, in order to ensure equality and justice among the students. Various activities were done, and classroom games were played, with a focus on related issues such as arranging fair seating in the classroom, being fair while giving the students the right to speak, allocating an equal amount of time to reply to the questions, and so forth.

Such activities both made the students well-prepared for the course and increased their interest and motivation. The researcher noted on the issue below:

"A game was played with sixth grade students to teach them some English vocabulary items for the purpose of giving them an equal chance to talk and equal opportunities. The teacher asked the meaning of a word to the student sitting at the front desk. If the student correctly and knew the meaning of the word, he continued to ask the meaning of another English word to the one sitting next to him and the game continued as a chain. The ones who could not remember the meanings of the words were eliminated. The students were allocated $10 \mathrm{~s}$ to give an answer. They were quite interested. Both the students who asked and those who replied were required to have a good knowledge of vocabulary, as the students who asked did not have the chance to check out their notes. The students stated that they liked the game very much, but they could enjoy it more if they had prepared for it in the following courses. Question and answer activities that were previously done for vocabulary caused negative feelings among the students, like being nervous and disconcerted. The game allowed them to be a bit more comfortable" (Week 1 ).

However, some of the activities that were done as a part of equal treatment and behavior needed changing, since they could not provide the expected outcomes, or they were not appreciated by the students. The researcher noted the issue below: 
"A name box was placed in the classroom, in order to ensure that everyone was given an equal right to speak in the classroom. The student who was to answer was defined by choosing a paper from the name box. Each student whose name was in the box answered once. The activity, which was designed with consideration of the students' expectations, could not bring about the desired effect, and it was canceled when they stated that the activity was boring, and it was not as interesting as they had expected" (Week 7).

"To ensure equality in the time allocated to the students for the answers, various instruments were used in the class. An hourglass was taken to the class once, and equal time was allocated to the students. The sixth graders especially liked the implementation. One of my students said that I had counted silently to give equal time and it was tiring for me but with the help of the hourglass, I did not need it anymore. The eighth graders commented that using an hourglass was childish. Thus, a classroom voting was held, and using the hourglass was abandoned. Using a chronometer was recommended, and it was approved unanimously" (Week 3).

\subsubsection{As a Part of Giving Clues/Supporting Other as the Subheading}

During the activity time, the teacher walked among the students' desks, the students were given close attention, they were given clues when needed, and they were helped. Pair work was done, and students were encouraged to support each other. Besides, students were helped by giving little hints during the games. The researcher noted on one of the assignments done in the groups below:

"Students' creative thinking skills were so suppressed that the students' expected me to set up the rules, even for the colors of the pens with which they wrote. I stressed that they were free and they could write whatever they imagined, provided that it was accurate and coherent with the topic. Even if they had a hard time at first, they successfully submitted assignments in the end. Such an activity also contributed to the communication between the students. I hesitated because the students could vote unfairly to select the best assignment to be exhibited on the board, but it did not happen. The one which was appreciated by everyone was hung on the board" (Week 2).

\subsubsection{As a Part of Intimacy/Interest/Valuing Others}

The students tried to improve their communication by having friendly conversations during break time. Moreover, the students' problems were cared about. Cooperation was established with the school counseling service, especially for the eighth graders, who became stressed about the centralized exams. The students' suggestions were valued and taken into consideration. Students' improvements were observed regularly by follow-up forms. Classroom rules were decided together with the students. The researcher noted on the implementations on intimacy/interest/valuing below:

"One of my students was surprised when I said "good morning" to him, as if he had seen me for the first time. I was disappointed by his reaction. I had not realized that I had forgotten an ordinary but important step before" (Week 1).

"Two eighth grade students who were remarkably worried were spoken to privately and asked if they had problems; if so, they could be helped. Both of the students spoke about their problems and requested for help" (Week 2).

In the following weeks, the implementations were done as a part of showing the intimacy/valuing process, and it was noticed by the students and appreciated mutually. The teacher commented on the issue below:

"In fact, I did these things from the first week. While I tried to reach the students at first, they found me and talked to me, and they had friendly, comfortable chats with me later" (Week 5).

"In one of the activities, students were asked to write a letter to themselves for a future time. I emphasized that the letters were going to be kept as memories, and they could even be reread in the future on a reunion day to talk over. All of the students liked the activity very much, and they submitted the letters that they elaborately wrote. The eighth graders especially commented that a future meeting could be possible as colleagues of the same school. That made me really happy" (Week 7). 


\subsubsection{As a Part of Appreciation and Motivation as the Subheading}

Words that showed appreciation and that used differing expressions (five different expressions at least) meant appreciation. Classroom rules were set together with the students. Activities to support students' positive behaviors were designed, and the students were rewarded. The teacher noted on the activities that supported positive student behaviors below:

"According to the rules defined by the sixth grade; positive behaviors received a blue card, and negative ones received a red card in each lesson. Previously, the cards had been selected as yellow and green, but the students wanted them to be the colors of the local football team, Düzcespor, and they were changed to be that way" (Week 4).

"The students started to confess when they made a mistake that they misbehaved and deserved red cards, but that they would not repeat the same negative behaviors. A group of students said that the English courses were far more different from the previous year. From now on, they would come to the class willingly when they saw English courses on their weekly schedule" (Week 11).

The SPSS program was used for data analysis. A dependent samples t-test was used, in order to determine whether there were any significant differences between the students' expectations about their teacher, and their attitudes towards the English course; a one-way repeated measures analysis of variance (ANOVA) was used was to determine whether there were any significant differences between the students' average scores, and for repeated tests; simple linear regression was used to determine the influence of teachers' expectancy on the students' attitudes and success. The significance level was defined as $p<0.05$. Concerning the normality of the data, the data was considered to be normal, based on the view that samples from a universe having a normal distribution and with independent observations are regarded to be distributed normally if the sample size is 30 or above $[36,37]$.

\section{Results}

\subsection{Did Teacher Expectancy Improvement Strategies Create Any Significant Differences in Students'} Expectations About the Teacher Before and After the Implementation?

A dependent samples t-test was used to see if whether there were any significant differences between the students' expectations about their teacher before and after the implementation, and the results were shown in Table 3.

Table 3. Students' Expectations about Their Teacher before and after the Implementation.

\begin{tabular}{|c|c|c|c|c|c|}
\hline & & Average Score & SD & $\mathbf{t}$ & $p$ \\
\hline \multirow{2}{*}{ Expectancy for equal treatment } & Pre-test & 4.29 & 0.57 & \multirow{2}{*}{-5.462} & \multirow{2}{*}{$0.000 *$} \\
\hline & Post-test & 4.60 & 0.33 & & \\
\hline \multirow{2}{*}{ Expectancy for giving clues } & Pre-test & 4.16 & 0.65 & \multirow{2}{*}{-7.865} & \multirow{2}{*}{0.000 * } \\
\hline & Post-test & 4.66 & 0.34 & & \\
\hline \multirow{2}{*}{$\begin{array}{l}\text { Expectancy for interest, } \\
\text { intimacy, valuing }\end{array}$} & Pre-test & 3.89 & 0.73 & \multirow{2}{*}{-9.539} & \multirow{2}{*}{0.000 * } \\
\hline & Post-test & 4.54 & 0.37 & & \\
\hline \multirow{2}{*}{$\begin{array}{l}\text { Expectancy for } \\
\text { appreciation/motivation }\end{array}$} & Pre-test & 4.02 & 0.82 & \multirow{2}{*}{-7.909} & \multirow{2}{*}{0.000 * } \\
\hline & Post-test & 4.64 & 0.38 & & \\
\hline
\end{tabular}

Students' expectancy scores after the implementation regarding expectancy for equal treatment, giving clues, interest/intimacy/valuing, and appreciation/providing motivation were seen to be higher, compared to their scores before the implementation. Statistically, the difference between the scores before and after the implementation was found to be meaningful $(p<0.05)$. 
3.2. Did Teacher Expectancy Improvement Strategies Create Any Significant Differences in Students' Attitudes towards the English Course before and after the Implementation?

A dependent sample t-test was used to see if there were any significant differences between the students' attitudes towards the English course, before and after the implementation, and the results are shown in Table 4.

Table 4. Students' Attitudes towards the English Course before and after the Implementation.

\begin{tabular}{|c|c|c|c|c|c|}
\hline & & Average Score & SD & $\mathbf{t}$ & $p$ \\
\hline \multirow{2}{*}{$\begin{array}{l}\text { Attitudes towards the } \\
\text { English Course }\end{array}$} & Pre-test & 3.75 & 0.70 & \multirow{2}{*}{-6.184} & \multirow{2}{*}{0.000 * } \\
\hline & Post-test & 4.16 & 0.61 & & \\
\hline
\end{tabular}

Students' attitude scores towards the English course after the implementation were seen to be higher than those of before the implementation. Statistically, there was a meaningful difference between the students' attitudes before and after the implementation $(p<0.05)$.

3.3. Did Teacher Expectancy Improvement Strategies Create Any Significant Differences in Students' Average Scores from the English Tests before and after the Implementation?

At the beginning of the implementation, the students' average scores were nine correct answers out of 20 questions, and the scores went up to 13 in the final test. A continuous increase in the scores was observed from each revision test done during the implementation. The graphics showing variations between the scores of the English tests are shown in Figure 1.

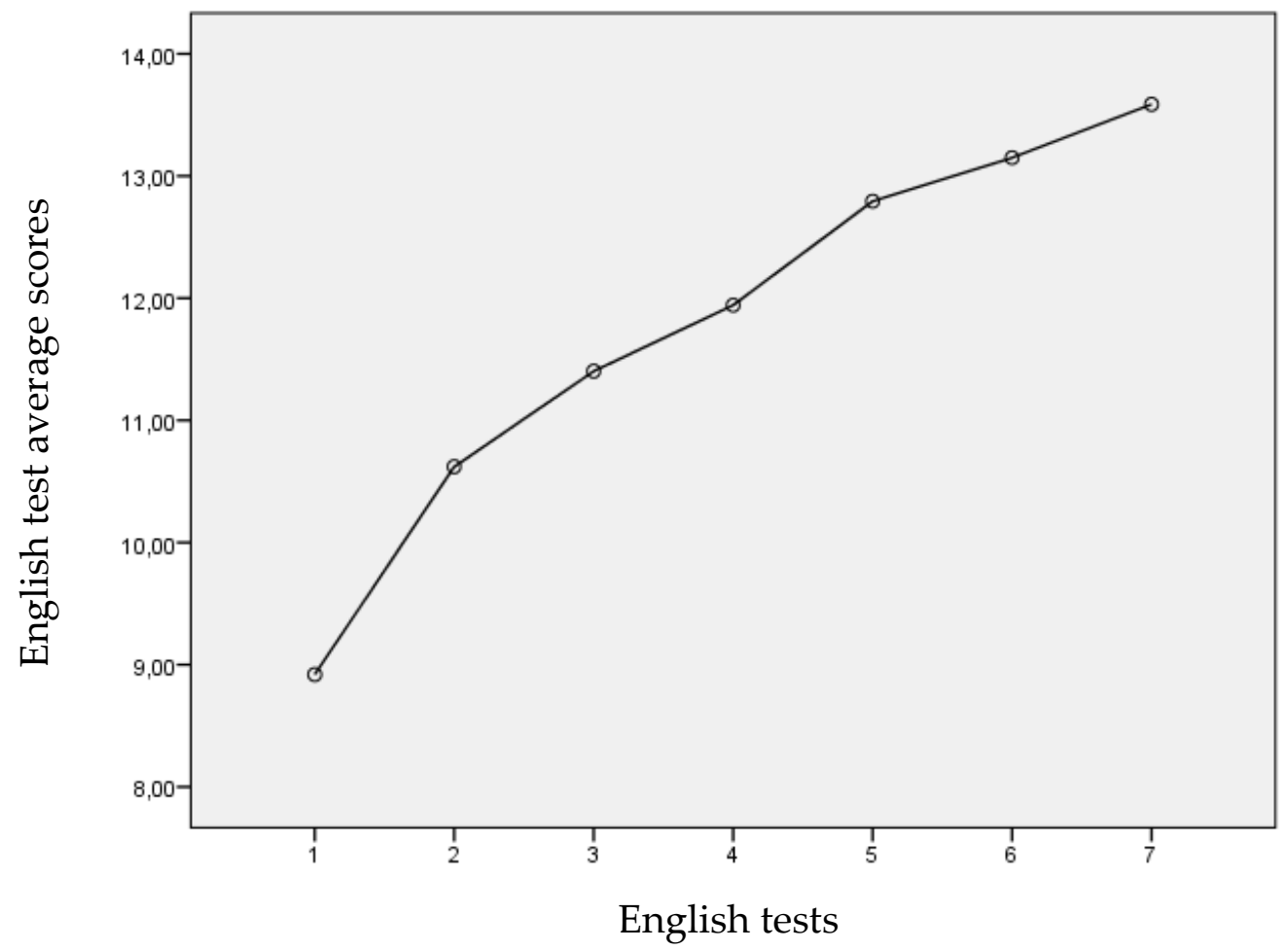

Figure 1. Graphics on Variations between the Students' Scores

One-way ANOVA with repeated measures were used to see if there were any significant differences between the students' average scores from the review tests. Since the Mauchly's test of sphericity hypothesis stipulating a homogeneity of variances between the scores could not be met, a variance analysis result, including Greenhouse-Geisser correction was shown in Table 5. 
Table 5. One way Repeated Measures Analysis of Variance (ANOVA) Results of English Review Tests Scores.

\begin{tabular}{ccccccc}
\hline Source of Variance & Sum of Squares & $\mathbf{d f}$ & Mean Square & F & $p$ & Significance \\
\hline Between groups & 7950.443 & 86 & 92.447 & & & $\begin{array}{r}1-2,1-3,1-4,1-5,1-6, \\
1-7,2-4,2-5,2-6, \\
2-7,3-5,3-6,3-7, \\
\text { Measure }\end{array}$ \\
& 1379.741 & 3.745 & 368.426 & 64.618 & 0.000 & $4-5,4-6,4-7,5-7,6-7$ \\
Error & 1384.545 & 322.066 & 3.555 & & & \\
\hline
\end{tabular}

As seen in the table, statistically meaningful differences between the students' English test scores were found in $\mathrm{F}(3.745-322.066)=64.618, p<0.01$. According to the calculated the effect size $\left(\eta^{2}=\right.$ $0.429) 43 \%$ of the difference could be explained. The results stated that significant differences were seen between the first test and all of the other tests; between the second test and the fourth, fifth, sixth, and seventh tests; between the third test and the fifth, sixth, and seventh tests; between the fourth test and the fifth, sixth, and seventh tests; between the fifth and seventh tests; between the sixth and seventh tests. There were no significant differences between the second and third; third and fourth; fifth and sixth tests. As a result, it might be reclaimed that higher expectancy strategies increased the students' success rates significantly.

\subsection{What was the Influence of Teacher Expectancy on the Students' Attitudes towards the English Course?}

The influence of teacher expectancy on the students' attitudes towards the English course was tested with simple linear regression, and the results were given in Table 6.

Table 6. Simple Linear Regression Analysis Results Predicting the Influence of Teacher Expectancy on the Students' Attitudes.

\begin{tabular}{cccccc}
\hline Variable & B & Standard Error & B & $\mathbf{t}$ & $p$ \\
\hline $\begin{array}{c}\text { Constant } \\
\text { Teacher }\end{array}$ & -1.888 & 0.850 & & -2.223 & 0.029 \\
expectancy & 1.311 & 0.184 & 0.612 & 7.127 & 0.000 \\
\hline \multicolumn{5}{r}{}
\end{tabular}

Note: $\mathrm{R}=0.612, \mathrm{R}^{2}=0.374, p<0.01$.

According to the results of the simple regression analysis, teacher expectancy had a significant influence on the students' attitudes towards the English course $\left(R=0.612, R^{2}=0.374, p<0.01\right)$. With reference to the result of the analysis, teacher expectancy explained $37 \%$ of the variance of the students' attitudes. When the standardized $\beta$ coefficient and $t$-values were examined, teacher expectancy was a significant predictor of the students' attitudes towards the English course.

3.5. What was the Influence of the Teacher Expectancy on the Students' Success Rates in the English Course?

The influence of the teacher expectancy on the students' success rates was tested with simple linear regression analysis, and the results are shown in Table 7.

Table 7. Simple Linear Regression Analysis Results Related with the Prediction of the Influence of Teacher Expectancy on the Students' Success.

\begin{tabular}{cccccc}
\hline Variable & B & Standard Error & B & t & $p$ \\
\hline $\begin{array}{c}\text { Constant } \\
\text { Teacher }\end{array}$ & -2.299 & 6.249 & & -0.368 & 0.714 \\
expectancy & 3.447 & 1.353 & 0.266 & 2.547 & 0.013 \\
\hline
\end{tabular}

Note: $\mathrm{R}=0.266, \mathrm{R}^{2}=0.071, p<0.05$. 
According to the simple linear regression analysis results, the teacher expectancy had a significant but lower rate of influence on the students' success $\left(R=0.266, R^{2}=0.071, p<0.05\right)$. Teacher expectancy explained $7 \%$ of the variance of the students' success. When the standardized $\beta$ coefficient and $t$-values were examined, teacher expectancy could be restated as a significant predictor of the students' attitudes towards the English course.

\section{Discussion, Conclusions, and Recommendations}

The first impressions that students have of a foreign language can generally be negative; they may think that it is difficult to understand, and boring. The negative stereotyping of students about language learning affects their motivation for language learning [35]. Changing negative beliefs and attitudes is the first step for success. For this, attitudes must first be determined, and necessary changes and innovations should be made in teaching [36]. Harmer [37] stated that motivation is effective in language teaching, and that individuals who teach languages should often express their students' success. With the encouragement of teachers, even those who are indifferent and unwilling to learn foreign languages can enter into a large studying atmosphere by being motivated to learn. As such, the positive attitudes and behaviors of the teachers lead to a positive learning environment for the students.

In this study, action research was planned, in order to develop a positive classroom environment in the English language, and to improve teacher expectation, in order to change negative beliefs and attitudes. To achieve this, the students need to be open to new knowledge, and the need to feel the desire to learn it [38]. In this context, the aim is to increase the positive attitudes and achievements of the students towards the English course, by using teacher expectation development strategies. Strategies developed to improve teacher expectations as a result of the literature review were collected under four headings: equal approach, giving clues, intimacy, and motivation. The strategies that were developed within this scope have been applied throughout the 12-week course. The action researcher kept daily observation notes, and revised the activities that were developed, according to the responses that she got from the students, and made changes where necessary.

In this study, whether teacher expectation development strategies have an effect on sixth and eighth-grade students' success and attitudes towards English was investigated. In this context, the results obtained in line with the sub-problems of the research are stated below.

It was determined that there were significant differences between the students' expectations from their teacher before and after the implementation of teacher expectancy strategies. Students' expectations for equal treatment, giving clues, showing interest, intimacy, valuing, appreciation, and providing motivation, significantly increased after the implementation, compared to their previous expectancy levels.

Using various course materials, playing games, giving clues, showing affection towards the children by conversing with them, and using appreciation statements for motivation, were made use of, in order to provide equal treatment to all students. This affected the students in the intended way, and influenced teacher expectancy after the implementation as well. The students also noticed the changing atmosphere of the classroom; their awareness was considered and noted by the researcher.

Teacher expectancy improvement strategies created a significant difference in the students' defined attitude scores before and after the implementation. The students' attitude scores were found to be higher after the implementation compared to the scores before the implementation process; it was also proven that teacher expectancy improvement strategies influenced the students' attitudes towards the English course as well. The students who were indifferent to the course, and claimed that they did not like the course, started to show more interest, and at the end of the process, they were observed to have an absence of negative tones. Teacher-student interactions improved when students took their teachers' expectations into consideration, and it influenced students' affective learning domain [38-40].

There were meaningful differences between the students' average scores from the English review tests, which were made during the teacher expectancy strategies improvement implementation process. Both the influence of the expectancy improvement strategies, and the changes in the students' attitudes 
in a positive way, also increased the students' success rates. While the students' average test score was nine correct answers out of 20 from the first review test, their scores went up to 13 correct answers in the final test. Similarly, the study carried out by Özer and Korkmaz [41] showed that teachers' positive attitudes and behaviors, giving each student the right to talk, and making them feel that their teacher cared about them, are the factors that influence students' success in foreign language learning. In another study, the findings showed that direct teacher expectancy effects had significant and positive effects on mathematics and literacy test results [42].

Moreover, another result obtained from the study was about the influence of teacher expectancy on the students' attitudes and students' success. That is, teacher expectancy was found to be a significant predictor of the students' attitudes and success. Previous studies on the issue showed that teacher expectations reflected on teachers' behaviors, and the reflection also influenced students' success [43-45]. The study by Rubbie-Davies, Hattie, and Hamilton [46], which was carried out on groups from four different ethnic origins, indicated that negative expectations about one of the groups caused them to fall behind, compared to the others during the final test-even though their previous test scores were closer to the other groups. Furthermore, Wubbels's study, done in 2003, showed that teachers' behaviors, in accordance with the expectations, had a 50\% influence on the students' attitudes towards courses [47]. Geçer and Deryakulu [48] stated in their study that teacher's intimacy as a significant predictor influenced students' success slightly, and in a positive way, and influenced students' attitudes moderately and in a positive way.

As a result of the study, teacher expectancy improvement strategies also caused students' expectancy levels to increase, and their attitudes and academic success rates were influenced in this way. The following recommendations could be made based on the findings:

(a) Cognitive learning characteristics should not be the first and foremost things that come to the mind. The affective domain should not be neglected, and it should be recognized that affective qualities also influence student success. Negative attitudes should be improved and turned into positive ones, and students should be motivated.

(b) Taking into account that a teacher behaves in accordance with their students' expectations; teachers' awareness of such expectations should be raised, and the teacher should take care to manage the students' expectations.

(c) It should be kept in mind that teacher expectancy increases students' positive attitudes and success; teachers could be provided in-service training on "teacher expectancy and expectancy management". Teachers should be encouraged to participate in such training, and care more about the issue.

(d) Various plans could be made to manage teacher expectancy, and it could become a unit for classroom management courses at education faculties.

(e) Considering the influence of teacher expectancy on success and attitude, the study could be made for other courses, except for English.

(f) Activity plans that cover a short period of time and that focus on limited issues could be prepared more comprehensively and implemented for an extended period of time.

Author Contributions: Conceptualization, S.T. and F.E.A.; Methodology, S.T. and F.E.A.; Software, S.T. and F.E.A.; Validation, S.T. and F.E.A.; Formal Analysis, S.T. and F.E.A.; Investigation, S.T. and F.E.A.; Resources, S.T. and F.E.A.; Data Curation, S.T. and F.E.A.; Writing-Original Draft Preparation, S.T. and F.E.A.; Writing-Review \& Editing, S.T. and F.E.A.; Visualization, S.T. and F.E.A.; Supervision, F.E.A.

Funding: This research received no external funding.

Conflicts of Interest: The authors declare no conflict of interest. 


\section{References}

1. Akın, E.; Çeçen, M.A. Çoklu ortama dayalı Türkçe öğretimine ve çoklu ortam araçlarına yönelik öğrenci görüşleri. Turk. Stud. 2015, 10, 51-72. [CrossRef]

2. Demirkan, C. Yabancı dil öğreniminin bireylerin sosyal yaşamına etkisi: Isparta'da öğretmenler üzerine bir araştırma. Master's Thesis, Süleyman Demirel Üniversitesi, Isparta, Turkey, 2008.

3. Aslanargun, E.; Süngü, H. Yabanci dil öğretimi ve etik. Milli Ĕ̆itim Derg. 2006, 34, 1-15.

4. Haznedar, B. Türkiye de yabancı dil eğitimi: Reformlar, yönelimler ve öğretmenlerimiz. In Proceedings of the International Conference on New Trends in Education and their Implications, Antalya, Turkey, 11-13 November 2010; pp. 747-755.

5. Işık, A. Yabancı dil eğitimimizdeki yanlışlar nereden kaynaklanıyor? J. Lang. Linguist. Stud. 2008, 4, 15-26.

6. Oğuzkan, T. Türkiye'de Ortaöğretim ve Sorunları; Dünya Tıp Kitabevi, Hisar Eğitim Vakfı Yayınları: İstanbul, Turkey, 1981.

7. Oroujlou, N.; Vahedi, M. Motivation, attitude, and language learning. Procedia Soc. Behav. Sci. 2011, 29, 994-1000. [CrossRef]

8. McDonough, J.; Shaw, C. Materials and Methods in ELT: A Teacher's Guide (Applied Language Studies); Blackwell: Oxford, UK, 1998; ISBN 978-0-631-18003-6.

9. Gardner, R.C.; Lambert, W.E. Attitudes and Motivation in Second-Language Learning; Newbury House Publishers: Rowley, MA, USA, 1972; ISBN 978-91-20-66090-5.

10. Gürel, H. Yabancı dil olarak İngilizce öğrenme başarısı ile öğrencilerin akademik benlik tasarımları ve tutumları arasındaki ilişki. Ph.D. Thesis, Hacettepe Üniversitesi, Ankara, Turkey, 1986.

11. Chambers, G.N. Motivating Language Learners; Multilingual Matters: Clevedon, UK, 1999; ISBN 978-1-85359-448-9.

12. Tatar, M. Öğretmen beklentisi. Yüzüncü Yıl Üniversitesi Eğitim Fakültesi Derg. 2005, 2, 1-19.

13. Brophy, J.E. Research on the Self-Fulfilling Prophecy and Teacher Expectations; Institute for Research on Teaching, College of Education, Michigan State University: East Lansing, MI, USA, 1982.

14. Good, T. Jere Brophy Teacher expectation as fulfilling prophecies. In Contemporary Issues in Educational Psychology; Clarizio, H.F., Craig, R.C., Mehrens, W.A., Eds.; Random House, Incorporated: New York, NY, USA, 1987; ISBN 978-0-394-35642-6.

15. Chang, J. A case study of the "Pygmalion Effect": Teacher expectations and student achievement. Int. Educ. Stud. 2011, 4, 198. [CrossRef]

16. Gershenson, S.; Papageorge, N. The power of teacher expectations: How racial bias hinders student attainment. Educ. Next 2018, 18, 65-70.

17. Öztürk, B.; Koç, G.; Şahin, F. Öğretmen beklentileri üzerine bir araştırma. Türkiye Sos. Araştırmalar Derg. 2002, 6, 123-144.

18. Brophy, J.E.; Good, T.L. Teachers' communication of differential expectations for children's classroom performance: Some behavioral data. J. Educ. Psychol. 1970, 61, 365-374. [CrossRef]

19. Allington, R.L. Teacher interruption behaviors during primary-grade oral reading. J. Educ. Psychol. 1980, 72, 371-377. [CrossRef]

20. Cooper, H.M.; Tom, D.Y. Teacher expectation research: A review with implications for classroom instruction. Elem. Sch. J. 1984, 85, 77-89. [CrossRef]

21. Öztürk, B.; Koç, G.; Şahin, F.T. Sınıf öğretmenlerinin yüksek ve düşük beklenti geliştirdikleri öğrencilere yönelik davranışlarının farklılaşma durumu. Ĕ̆itim Bilim. ve Uygul. 2002, 1, 161-181.

22. Gökdere, E. Öğretmen beklentilerinin yönetimi. 21. Yüzyılda Eğitim ve Toplum, Eğitim Bilim.ve Sos. Araştırmalar Derg. 2013, 2, 179-183.

23. Curry, L.M. Effective teaching through high expectation and class management. USA Gymnast. Online Tech. 2000, 20, 1-3.

24. McDonald, L.; Flint, A.; Rubie-Davies, C.M.; Peterson, E.R.; Watson, P.; Garrett, L. Teaching high-expectation strategies to teachers through an intervention process. Prof. Dev. Educ. 2016, 42, 290-307. [CrossRef]

25. Fines, B.G. The Impact of Expectations on Teaching and Learning; Social Science Research Network: Rochester, NY, USA, 2008.

26. America, T.F.; Farr, S.; Kamras, J.; Kopp, W. Teaching as Leadership: The Highly Effective Teacher's Guide to Closing the Achievement Gap; Wiley: Hoboken, NJ, USA, 2010; ISBN 978-0-470-59306-6. 
27. Reynold, M.C. Ten Strategies for Creating a Classroom Culture of High Expectations; South Regional Education Board: Atlanta, GA, USA, 2000.

28. Cantor, J.; Kester, D.; Miller, A. Amazing Results! Teacher Expectations and Student Achievement (TESA) Follow-Up Survey of TESA-Trained Teachers in 45 States and the District of Columbia; 2000. Available online: https: / files.eric.ed.gov/fulltext/ED443801.pdf (accessed on 18 July 2017).

29. Gottfredson, D.C. Increasing Teacher Expectations for Student Achievement: An Evaluation. Report No. 25; Center for Research on Efective Scholing for Disadvantaged Students: Baltimore, MD, USA, 1991.

30. Norton, L. Action research in teaching and learning: A practical guide to conducting pedagogical research in universities; 2009th ed.; Routledge: New York, NY, USA, 2009; ISBN 978-0-415-46846-6.

31. Costello, P.J.M. Action Research; Continuum Books: London, UK, 2007; ISBN 978-0-8264-6479-8.

32. Kuzu, A. Öğretmen yetiştirme ve mesleki gelişimde eylem araştırması. Uluslar. Sos. Araştırmalar Derg. 2009, 2, 425-433.

33. Altricher, H.; Feldman, A.; Posch, P.; Somekh, B. Teachers Investigate Their Work: An Introduction to Action Research across the Professions; Routledge: London, UK, 2005; ISBN 978-1-134-87077-6.

34. Mills, G.E. Action Research a Guide for the Teacher Researcher, 2nd ed.; Merrill/Prentice Hall: Upper Saddle River, NJ, USA, 2003; ISBN 0-13-042254-1.

35. Kirkiz, M.A. Öğrencilerin İngilizce dersine ait tutumları ile akademik başarıları arasındaki ilişki. Master's Thesis, Trakya Üniversitesi, Edirne, Turkey, 2010.

36. Roussas, G.G. Introduction to Probability; Elsevier Science: Amsterdam, The Netherlands, 2007; ISBN 978-0-12-088595-4.

37. Wilcox, R. Modern Statistics for the Social and Behavioral Sciences: A Practical Introduction; CRC Press: Boca Raton, FL, USA, 2012; ISBN 978-1-4665-0323-6.

38. Gorham, J. The relationship between verbal teacher immediacy behaviors and student learning. Commun. Educ. 1988, 37, 40-53. [CrossRef]

39. Christophel, D.M. The relationships among teacher immediacy behaviors, student motivation, and learning. Commun. Educ. 1990, 39, 323-340. [CrossRef]

40. Christensen, L.J.; Menzel, K.E. The linear relationship between student reports of teacher immediacy behaviors and perceptions of state motivation, and of cognitive, affective, and behavioral learning. Commun. Educ. 1998, 47, 82-90. [CrossRef]

41. Özer, B.; Korkmaz, C. Yabancı dil öğretiminde öğrenci başarısını etkileyen unsurlar. Ekev Akad. Derg. 2016, $20,59-84$.

42. Trusz, S. Four mediation models of teacher expectancy effects on students' outcomes in mathematics and literacy. Soc. Psychol. Educ. 2018, 21, 257-287. [CrossRef]

43. Harris, M.J.; Rosenthal, R. Four factors in the mediation of teacher expectancy effects. In The Social Psychology of Education: Current Research and Theory; Cambridge University Press: New York, NY, USA, 1986; pp. 91-114. ISBN 978-0-521-30620-1.

44. Sheftall, M.S. Teacher expectations, teacher efficacy, and student achievement. 2001. Available online: https:/ / elibrary.ru/item.asp?id=5326917 (accessed on 13 November 2018).

45. Tauber, R.T. Self-Fulfilling Prophecy: A Practical Guide to Its Use in Education; Greenwood Publishing Group: Santa Barbara, CA, USA, 1997; ISBN 978-0-275-95502-1.

46. Rubie-Davies, C.; Hattie, J.; Hamilton, R. Expecting the best for students: Teacher expectations and academic outcomes. Br. J. Educ. Psychol. 2006, 76, 429-444. [CrossRef]

47. Saydam, G.; Telli, S. Eğitimde bir araştırma alanı olarak sınıfta öğrenci-öğretmen kişilerarası iletişimi ve öğretmen etkileşim ölçeği (QTI). Boğaziçi Üniversitesi Ĕ̆itim Derg. 2011, 28, 23-45.

48. Geçer, A.; Deryakulu, D. Öğretmen yakınlığının öğrencilerin başarıları, tutumları ve güdülenme düzeyleri üzerindeki etkisi. Kuram ve Uygulamada Ĕ̆itim Yönetimi 2004, 10, 518-543.

(C) 2019 by the authors. Licensee MDPI, Basel, Switzerland. This article is an open access article distributed under the terms and conditions of the Creative Commons Attribution (CC BY) license (http:/ / creativecommons.org/licenses/by/4.0/). 